\title{
Steun voor traditionele vrouwenrollen in 32 landen \\ De invloed van gezinsbeleid en verschillen tussen de seksen
}

\author{
Stéfanie André, Maurice Gesthuizen \& Peer Scheepers ${ }^{1}$
}

\section{Summary}

Support for traditional female roles in 32 countries. Family policy models and gender differences

Cross-national research on support of traditional female roles is scarce. This research fills this knowledge gap by studying 32 countries around the world, to provide insight into categories that support or reject traditional female roles. We test individual and contextual explanations for differences in the support of traditional female roles within and between countries as well as between men and women. We find that the differences between individuals are larger than between countries. We explain the differences with a combination of individual and contextual characteristics. Higher educated, employed people and those who do not adhere to a religion are the least supportive of traditional female roles. It turns out that people living under a dual earner family policy model support traditional female roles least strongly. Furthermore, we do not find the gender gap to be significantly different in countries with a dual-earner family policy model as compared to traditional countries, but we do find smaller gender differences in countries with other family policy models.

\section{Introductie en onderzoeksvragen}

Gelijke rechten, plichten en behandeling van mannen en vrouwen is tegenwoordig een belangrijk doel van beleid. De Europese Unie heeft de 'Framework Strategy for Equality' (2001-2005) en de 'Roadmap for Equality' (2006-2010) opgezet, waarin zes speerpunten staan om gelijkheid tussen de seksen te promoten (Europa.eu, 2010). Wanneer iemand bijvoorbeeld denkt dat een moeder met een kind dat nog niet naar school gaat, 
niet zou moeten werken, is dat een traditionele houding met betrekking tot vrouwenrollen. Er wordt verwacht dat met de zes speerpunten de houding van Europeanen kan worden beïnvloed over de (maatschappelijke) rollen die mannen en vrouwen kunnen vervullen, zodat de gemiddelde Europeaan een minder traditionele houding ontwikkelt ten opzichte van vrouwenrollen.

Er is nog maar weinig bekend over de steun voor traditionele vrouwenrollen vanuit een crossnationaal perspectief. Ook weten we weinig over verschillen tussen landen in de mate waarin mannen en vrouwen (anders) denken over traditionele vrouwenrollen. Om onze kennis over de steun voor traditionele vrouwenrollen te vergroten richten we ons op individuele determinanten, op contextuele determinanten, zoals het gezinsbeleid in een land, en op verschillen tussen mannen en vrouwen in 32 landen. Gezinsbeleid heeft betrekking op het beleid in een land om de combinatie van arbeidsmarktparticipatie door vrouwen en zorg voor het gezin te steunen of te ontmoedigen. We veronderstellen dat dergelijk nationaal beleid de mate van steun voor traditionele vrouwenrollen van individuen in dat land beïnvloedt. Het is ons doel om inzicht te verschaffen in de steun voor traditionele vrouwenrollen, door te onderzoeken welke sociale categorieën traditionele vrouwenrollen meer of minder ondersteunen, in hoeverre het gezinsbeleid in een land van invloed is op de steun voor traditionele vrouwenrollen, en in hoeverre en waarom er crossnationale variatie is in de verschillen tussen mannen en vrouwen in de steun voor traditionele vrouwenrollen. Deze informatie kan uiteindelijk gebruikt worden om nationaal en Europees beleid vorm te geven.

Onderzoek naar de steun voor traditionele vrouwenrollen komt vanaf de jaren zeventig voornamelijk op in de Verenigde Staten (Amato \& Booth, 1995; Bolzendahl \& Myers, 2004; Brooks \& Bolzendahl, 2004; Kane, 2000), al zijn er ook studies gedaan in andere landen, zoals GrootBrittannië (Berridge, Penn \& Ganjali, 2009). Een overzicht van, voornamelijk nationale, studies naar de steun voor traditionele vrouwenrollen staat beschreven in Gibbons, Hamby en Dennis (1997). Ook zijn er studies waarin de steun voor traditionele vrouwenrollen in crossnationaal perspectief wordt geplaatst. Panayatova en Brayfield (1997) bestudeerden traditionele vrouwenrollen in Hongarije en de Verenigde Staten in 1988, Davis en Robinson (1991) onderzochten Groot-Brittannië, de Verenigde Staten, Oostenrijk en West-Duitsland in 1985/1986, Motiejunaite en Kravchenko (2008) richtten zich op Rusland en Zweden in 1994 en 2002 en Sjöberg (2004) bestudeerde dertien geïndustrialiseerde landen in 1994. Over het algemeen vond men in deze studies dat mannen, werklozen en gehuwden traditionele vrouwenrollen meer steunen. Uit de crossnationale studies bleek bovendien dat de steun voor traditionele vrouwenrollen lager is in landen met een hoger percentage vrouwen op de arbeids- 
markt. Het is echter onbekend in hoeverre landen binnen de Europese Unie van elkaar verschillen en of er verschillen zijn tussen Europese en niet-Europese landen. Wij willen een bijdrage leveren aan de kennis over de steun voor traditionele vrouwenrollen door meer landen te onderzoeken. We vergroten het domein van het onderzoek door 32 landen in 2002 te onderzoeken. Omdat we meer (Europese en niet-Europese) landen tegelijk bestuderen, is het mogelijk om een breder patroon te schetsen van de verschillen en overeenkomsten in de steun voor traditionele vrouwenrollen in de wereld en om verklaringen te onderzoeken voor zulke verschillen.

Naast de algemene verschillen tussen landen zijn we ook geïnteresseerd in hoeverre het verschil tussen de seksen tussen landen varieert wat betreft de steun voor traditionele vrouwenrollen. Uit eerder onderzoek bleek dat mannen traditioneler denken over vrouwenrollen dan vrouwen (Amato \& Booth, 1995; Berridge, Penn \& Ganjali, 2009; Bolzendahl \& Myers, 2004; Carter, Corra \& Carter, 2009; Cassidy \& Warren, 1996; Cherlin \& Walters, 1981; Gibbons, Hamby \& Dennis, 1997; Harris \& Firestone, 1998; Mason \& Lu, 1988). Het verschil in steun tussen mannen en vrouwen is nog niet eerder uitgebreid onderzocht in een crossnationale setting: daardoor weten we niet of deze verschillen van vergelijkbare grootte zijn tussen landen. We gebruiken de recentste grootschalige crossnationale databron waar steun voor traditionele vrouwenrollen vergelijkbaar in is gemeten. We beschrijven de crossnationale verschillen in een groot aantal Europese en niet-Europese landen door antwoord te geven op onze eerste onderzoeksvraag: in hoeverre varieert het verschil tussen mannen en vrouwen in hun steun voor traditionele vrouwenrollen tussen landen in 2002?

Na de steun voor traditionele vrouwenrollen beschreven te hebben in 32 landen willen we de verschillen verklaren tussen individuen en landen. Voor dit doel leiden we hypothesen af uit een theoretisch kader dat gebaseerd is op twee perspectieven: socialisatie en rationele keuze. Een verbetering ten opzichte van eerder onderzoek is dat we ook verklaringen ontwikkelen op contextueel niveau en deze verklaringen empirisch toetsen. Dit is, op het onderzoek van Sjöberg (2004) na, nog niet eerder uitgebreid gedaan. Onze tweede onderzoeksvraag luidt: in hoeverre kunnen verschillen in steun voor traditionele vrouwenrollen in 2002 worden verklaard met individuele en contextuele kenmerken?

Tot slot onderzoeken we in hoeverre de crossnationaal variërende kloof tussen mannen en vrouwen in steun voor traditionele vrouwenrollen beïnvloed wordt door contextuele kenmerken. We onderzoeken hiermee de mogelijkheid dat specifieke kenmerken van het land waarin mensen wonen, vooral wat betreft het gezinsbeleid, verschillende effecten hebben op mannen en vrouwen. In eerder onderzoek (Sjöberg, 2004) 
werd verondersteld dat er sprake zou zijn van uniforme contextuele effecten, waardoor geen aandacht werd besteed aan de mogelijkheid dat mannen op een andere manier beïnvloed worden door de context waarin ze leven dan vrouwen. Wanneer het gezinsbeleid er echter toe zou leiden dat de verschillen tussen mannen en vrouwen groter worden, bijvoorbeeld doordat vrouwen onder zulke omstandigheden sterker beïnvloed worden dan mannen, dan worden met zulk beleid de tegenstellingen vergroot. Men kan zich dan afvragen of het beleid wel effectief genoeg is. Onze laatste onderzoeksvraag luidt daarom: in hoeverre verschillen contextuele verklaringen voor de steun voor traditionele vrouwenrollen voor mannen en vrouwen?

Een laatste verbetering ten opzichte van eerder onderzoek is methodologisch van aard en betreft de vergelijkbaarheid van het meetmodel. We stellen vast in hoeverre ons meetmodel voor steun voor traditionele vrouwenrollen gelijk is in de 32 landen in ons onderzoek. Dit is een belangrijke voorwaarde waaraan voldaan dient te worden in crossnationaal onderzoek (Van de Vijver \& Leung, 1997). Het wordt echter vaak nagelaten meetmodellen te onderzoeken op crossnationale equivalentie.

\section{Theorieën en hypothesen}

Bolzendahl en Myers (2004) geven twee theoretische verklaringen voor 'support of gender role equality', die ook toegepast kunnen worden op steun voor traditionele vrouwenrollen. Deze twee verklaringen kunnen in een breder sociologisch theoretisch perspectief worden geplaatst. De eerste verklaring, gebaseerd op blootstelling aan normen, kan afgeleid worden uit de socialisatietheorie (Stark, 2004). De tweede verklaring, gebaseerd op het belang dat men kan hebben bij traditionele rollen voor vrouwen, vindt zijn oorsprong in de rationele-keuzetheorie (Downs, 1957). We gebruiken beide theorieën om hypothesen uit af te leiden.

2. I De invloed van individuele kenmerken op steun voor traditionele vrouwenrollen Stark (2004) stelt dat socialisatie een levenslang proces is waarin mensen zich eigen maken hoe ze zich horen te gedragen en wat ze horen te denken. Tegelijkertijd is er sprake van differentiële socialisatie: meisjes en jongens worden anders gesocialiseerd en dit wordt gebaseerd op de verwachtingen die mensen (hun ouders maar ook anderen die een rol spelen in de socialisatie) hebben over de op sekse gebaseerde rollen die ze later zouden moeten vervullen. Hierdoor kunnen we verwachten dat jongens en meisjes ook andere meningen hebben omtrent steun voor traditionele vrouwenrollen. Mensen worden een leven lang gesocialiseerd volgens bepaalde normen in een groep en deze kunnen meer tradi- 
tioneel of meer egalitair zijn, waardoor steun voor of afwijzing van traditionele vrouwenrollen wordt aangemoedigd (Durkheim, 1922; Stark, 2004). Daarom zullen we de levensloop van een persoon volgen en leiden we verwachtingen af over de effecten van individuele kenmerken op steun voor traditionele vrouwenrollen.

De primaire bron van socialisatie voor een kind zijn de ouders. Ouders leren hun kinderen om hun sekse te zien als een belangrijk kenmerk op basis waarvan de wereld kan worden geordend (Newman, 2000; Plutzer, 1988, 2002). Ouders socialiseren hun kinderen volgens hun verwachtingen over hoe de kinderen zich moeten gedragen als volwassenen (Kohn \& Schooler, 1982). Werkende moeders verwachten van hun kinderen - inclusief hun dochters - dat ze als volwassenen ook werken en dat ze een rol aannemen (werken) die voorheen alleen voor mannen was weggelegd. Daarom verwachten we dat kinderen van werkende moeders minder steun uitdragen voor traditionele vrouwenrollen dan kinderen van niet-werkende moeders. Dit is ook aangetoond in eerder onderzoek (Banaszak \& Plutzer, 1993; Bolzendahl \& Myers, 2004; Klein, 1984; Motiejunaite \& Kravchenko, 2008). De 'werkende-moeder hypothese' luidt: mensen van wie de moeder werkte in de jeugd, steunen de traditionele vrouwenrollen minder dan mensen waarvan de moeder niet werkte in de jeugd.

Kinderen worden ook gesocialiseerd in verschillende maatschappelijke omstandigheden. Oudere cohorten werden in een sociaalhistorisch milieu gesocialiseerd waarin de rollen van vrouwen traditioneler waren en de houdingen over seksegelijkheid minder emancipatoir (Bolzendahl \& Myers, 2004; Brewster \& Padavic 2000; Davis \& Robinson, 1991). We verwachten dan ook dat oudere cohorten traditionele vrouwenrollen meer zullen steunen dan jongere cohorten. De 'cohorthypothese' luidt: mensen die behoren tot de jongere cohorten steunen de traditionele vrouwenrollen minder dan mensen uit oudere cohorten.

De jeugd wordt via het opleidingssysteem morele waarden aangeleerd. Jongeren op school worden daarmee gesocialiseerd volgens bepaalde normen, waaronder normen die betrekking hebben op sekserollen en de steun voor traditionele vrouwenrollen. Uit eerder onderzoek bleek dat een langere blootstelling aan socialisatie binnen het opleidingssysteem samengaat met minder steun voor traditionele vrouwenrollen (Berridge, Penn \& Ganjali, 2009; Cassidy \& Warren, 1996; Davis \& Robinson, 1991; Mason \& Lu, 1988). Mensen die deelnemen aan hogere onderwijsniveaus, blijven langer in het opleidingssysteem en worden daarom langer blootgesteld aan en gesocialiseerd door de egalitaire norm (Gesthuizen, Van der Meer \& Scheepers, 2008). De 'opleidingshypothese' kan hieruit worden afgeleid: mensen met een hoger opleidingsniveau steunen traditionele vrouwenrollen minder dan mensen met een lager opleidingsniveau. Er is tevens een rationele keuze-element ter verklaring van deze hypothese. Hoger 
opgeleide vrouwen zullen eerder een carrière willen in plaats van of naast een gezin. Zij zijn erbij gebaat als het hebben en nastreven van een carrière wordt geaccepteerd en bevorderd, naast de rol als moeder. Daarnaast zullen zij cognitieve dissonantie tussen hun gedrag (carrière) en houding willen beperken. Daarom is het voor hen gunstiger om traditionele vrouwenrollen niet te steunen (Bolzendahl \& Myers, 2004).

Na de opleiding starten de meeste mensen een carrière op de arbeidsmarkt, een rol die lange tijd alleen was weggelegd voor mannen. Aangezien de arbeidsmarktparticipatie van vrouwen is toegenomen (ILO 2010b), verwachten we dat de algemene norm binnen de beroepsbevolking tegenwoordig voor niet-traditionele vrouwenrollen is. Buitenshuis werken duidt dan op een sterkere socialisatie in de norm van niet-traditionele vrouwenrollen. Ook hier kunnen argumenten vanuit het rationele keuze perspectief gelden. Wanneer een vrouw een baan heeft, is het rationeel voor haar geen steun te betuigen aan traditionele vrouwenrollen, aangezien deze haar 'verbieden' te werken. Deze houding van vrouwen in de beroepsbevolking beïnvloedt tevens de algemene norm en dus ook mannen. De 'arbeidshypothese' luidt: mensen die werken, steunen traditionele vrouwenrollen minder dan mensen die niet werken.

Veel mensen beginnen een gezin nadat ze op de arbeidsmarkt zijn begonnen, daarmee begint een nieuwe levensfase (Bolzendahl \& Myers, 2004; Cassidy \& Warren, 1996). Het is aangetoond dat mensen die getrouwd zijn of samenwonen traditionele vrouwenrollen meer steunen: dit is waarschijnlijk het geval omdat ze een meer traditionele rol aannemen (Jansen \& Kalmijn, 2000; Waite, Goldscheider \& Witsberger, 1986). Het kan ook zijn dat mensen die een niet-traditionele rol hebben, hun houding veranderen, omdat dit rationeel voor hen is (het beperkt de cognitieve dissonantie). Jansen en Kalmijn (2000) hebben aangetoond dat de houding het gedrag beïnvloedt, maar ook dat het gedrag de houding beïnvloedt. We veronderstellen dat ook het aantal kinderen een effect heeft. Het hebben van meer kinderen zou kunnen duiden op een traditioneler gezinsleven, hetgeen mogelijk samengaat met meer steun voor traditionele vrouwenrollen. Enkele onderzoekers bevestigen dit verband (Penn \& Lambert, 2002). Bolzendahl en Myers (2004) vonden daarentegen een negatief effect van het aantal kinderen op de steun voor traditionele vrouwenrollen, terwijl Cassidy en Warren (1996) geen effect vonden. De 'gezinshypothese' luidt als volgt: getrouwde en samenwonende mensen en mensen met kinderen steunen traditionele vrouwenrollen meer dan ongehuwde, niet samenwonende mensen en mensen zonder kinderen.

Socialisatie vindt ook plaats in religieuze organisaties (Stark, 2004). Religieuze instituten zijn niet altijd tegen egalitaire rollen voor mannen en vrouwen, maar ze dragen doorgaans wel bij aan houdingen ten gunste van traditionele vrouwenrollen. De religieuze instituten vertellen 
hun volgelingen wat te denken en wat te doen: op deze manier socialiseren ze hen volgens een bepaalde norm met betrekking tot traditionele vrouwenrollen. Zo benadrukt de islam, zoals vertegenwoordigd door religieuze leiders, de scheiding tussen mannen en vrouwen (Mernissi, 1985), vaak gebaseerd op Soera 4:34 (www.koranonline.nl). In de Bijbel, bijvoorbeeld in Genesis 3:16, wordt beschreven dat de man heerst over zijn vrouw (www.bijbel-online.nl). Uit eerder onderzoek blijkt dat binnen de groep gelovigen, protestanten deze traditionele vrouwenrollen het meest steunen, gevolgd door katholieken, terwijl joden traditionele vrouwenrollen het minst steunen (Bolzendahl \& Myers, 2004). Daarom verwachten we in onze 'religiehypothese' dat: mensen die lid zijn van een religieuze organisatie traditionele vrouwenrollen meer steunen dan mensen die niet tot een religieuze organisatie behoren. Binnen de groep religieuzen steunen joden traditionele vrouwenrollen het minst en moslims het meest.

We houden ook rekening met de mate van religieuze integratie. Het is te verwachten dat hoe sterker personen zijn geïntegreerd in een religieuze gemeenschap, des te meer ze zich zullen houden aan de normen van deze gemeenschap met betrekking tot traditionele vrouwenrollen. Dit wordt bevestigd door eerder onderzoek waaruit bleek dat kerkbezoek een positief effect heeft op de steun voor traditionele vrouwenrollen (Plutzer, 1988; Sjöberg, 2004; Brooks \& Bolzendahl, 2004; Carter, Corra \& Carter, 2009; Motiejunaite \& Kravchenko, 2008). De 'religieuze integratie hypothese' luidt: hoe vaker men diensten bezoekt van een religieuze organisatie, des te meer steunt men traditionele vrouwenrollen.

In eerder onderzoek bleken enkele andere individuele kenmerken effect te hebben op de steun voor traditionele vrouwenrollen (Bolzendahl \& Myers, 2004; Boye, verwacht; Brooks \& Bolzendahl, 2004; Carter, Corra, \& Carter, 2009). In onze analyses controleren we daarom voor vier andere individuele kenmerken: het inkomen, het aantal uren besteed aan het huishouden door de respondent en zijn of haar partner en de urbanisatiegraad.

\subsection{De invloed van contextuele kenmerken op steun voor traditionele vrouwenrol- len}

Socialisatie is een proces waarin iemand leert zich te gedragen volgens bepaalde regels en verwachtingen (Newman, 2000) en alle maatschappijen hebben differentieel gesocialiseerde mensen op het gebied van [sekse] (Stark, 2004, 164). Het meeste onderzoek heeft zich gericht op het individuele niveau, maar de context kan de houding inzake traditionele vrouwenrollen ook beïnvloeden. Crossnationale studies vonden verschillen tussen landen in de steun voor traditionele vrouwenrollen die niet verklaard konden worden door individuele kenmerken (Motiejunaite \& Kravchenko, 2008; 
Sjöberg, 2004). Er zijn meerdere studies die beargumenteren en onderzoeken in hoeverre verzorgingsstaten met verschillend beleid (EspingAndersen, 1990; 1999) een socialiserende context vormen en daarmee de houdingen en het gedrag beïnvloeden van individuen (Bonoli, 1997; Fridberg \& Ploug, 2000; Gelissen, 2000; Gundelach, 1994; Scheepers \& Te Grotenhuis, 2005; Svallfors, 1997). Met zijn typologie van verzorgingsstaten maakt Esping-Andersen $(1990,1999)$ onderscheid tussen het sociaaldemocratische, conservatiefcorporatistische en liberale regime. Deze typologie werd later uitgebreid met het mediterrane regime (Bonoli, 1997; Ferrera, 1996; Liebfried, 1992). Verschillende auteurs achtten de karakterisering van Esping-Anderson te beperkt: een groot punt van kritiek is dat het te veel op het mannelijke kostwinnersmodel is gericht. Voornamelijk voor onderzoek naar sekserollen kan een gespecificeerder onderscheid vruchtbaar zijn (Guo \& Gilbert, 2007; Korpi, 2000).

Dit onderscheid wordt gemaakt door uit te gaan van het gezinsbeleid. Sjöberg (2004) verwachtte dat gezinsbeleidmodellen invloed zouden hebben op de individuele houding tegenover traditionele vrouwenrollen. In een studie naar dertien geïndustrialiseerde landen bleek dit het geval te zijn. De gezinsbeleidmodellen zijn gebaseerd op twee criteria. Het eerste is de mate van steun voor het tweeverdienersmodel, waarin beide partners werken en kinderopvang wordt verzorgd door de staat. Het tweede criterium is de mate van steun voor het traditionele model waarin vrouwen thuis blijven en voor de kinderen zorgen. Gebaseerd op beide criteria maakt Korpi (2000) onderscheid tussen drie soorten gezinsbeleidmodellen: het tweeverdienersmodel, het traditionele model en het marktgeoriënteerde model. Deze typologie is uitgebreid door Ferrarini met het tegenstrijdigheidsmodel, dat voor de Oost-Europese landen geldt (Ferrarini, 2006). Landen die het traditionele model steunen, stimuleren de vrouwelijke arbeidsmarktparticipatie niet en benadrukken de traditionele rol van vrouwen als verzorgsters. Landen met het tweeverdienersmodel stimuleren vrouwelijke arbeidsmarktparticipatie en faciliteren kinderopvang. In een marktgeoriënteerd model biedt de overheid geen diensten aan vrouwen om actief te worden op de arbeidsmarkt, maar laat het aanbieden van deze diensten over aan de markt. Het tegenstrijdigheidmodel bestaat uit steun voor zowel het tweeverdieners- als voor het traditionele gezin. Het wordt tegenstrijdig genoemd, omdat dit model uitgaat van een tegenstrijdige keuze tussen steun voor tweeverdieners en traditionele gezinnen. Deze gezinsbeleidmodellen worden verondersteld te zijn voortgekomen uit de algemene norm in een land over traditionele vrouwenrollen. De modellen kunnen op hun beurt de houding van mensen versterken (Korpi, 2000). Dit betekent dat de causaliteit beide kanten op kan gaan, zoals op individueel niveau is aangetoond door Jansen \& Kalmijn (2000). We verwachten dat de vor- 
men van beleid die de mogelijkheden beïnvloeden van vrouwen om gebruik te maken van andere rollen als moederschap, invloed hebben op de steun voor traditionele vrouwenrollen van iedere inwoner van een land. Deze beleidsmodellen geven een signaal af naar de inwoners welke normen worden gesteund door de regering. De 'gezinsbeleidhypothese' luidt daarom: mensen in landen met een tweeverdienersgezinsbeleid steunen traditionele vrouwenrollen het minst, en mensen in landen met een traditioneel gezinsbeleidmodel steunen traditionele vrouwenrollen het meest, terwijl mensen die in landen leven met het tegenstrijdig gezinsbeleidmodel hier tussenin zitten.

\section{3 'Cross-level'-interacties}

Contextuele determinanten kunnen verschillende effecten voor mannen en vrouwen hebben vanwege differentiële socialisatie (Stark, 2004). Dit betekent dat het socialiserende effect dat we verwachten van gezinsbeleidmodellen zou kunnen verschillen voor de seksen. Het gezinsbeleidsmodel waarin de nadruk ligt op tweeverdieners maakt voornamelijk opties mogelijk voor vrouwen (Sjöberg, 2004). Wanneer een gezinsbeleidsmodel is gebaseerd op beleid ten gunste van tweeverdieners waarin vrouwen en mannen werken en waarin de staat zorg draagt voor de kinderopvang, verwachten we dat dit een effect heeft op de houdingen van vrouwen en mannen. Echter, omdat vrouwen bij voorbaat al minder steun verlenen aan traditionele vrouwenrollen en vooral bij mannen ruimte is om minder traditioneel te worden, zal de grootste afname mogelijk bij mannen te vinden zijn. Hieruit leiden we de 'cross-level-interactiehypothese' af: in landen waar het gezinsbeleidmodel is gebaseerd op het tweeverdienermodel is het verschil tussen vrouwen en mannen wat betreft de steun voor traditionele vrouwenrollen kleiner dan in landen met traditioneel gezinsbeleid. Voor de vergelijking tussen de overige gezinsbeleidmodellen leiden we geen hypothesen af, maar laten we het aan de empirie over in hoeverre sekseverschillen in steun voor traditionele vrouwenrollen kleiner of groter zijn.

\section{Data, meetinstrumenten en methode}

We gebruiken data van het 'International Social Survey Programme' (ISSP). Dit is een jaarlijks grootschalig crossnationaal onderzoek over onderwerpen die belangrijk zijn voor de sociale wetenschappen (ISSP, 2010). We hebben de in de ISSP roterende module 'Family and Changing Gender Roles' gebruikt uit 2002, dit is de recentste versie. We hebben alle landen bestudeerd die deelnamen in 2002. Dit zijn er 35 in totaal. 


\section{I Afhankelijke variabele}

Sekserollen hebben betrekking op verschillende levensdomeinen (Stark, 2004) en dit is ook het geval met de steun voor meer of minder traditionele sekserollen. Houdingen tegenover sekserollen hebben betrekking op de rollen die men voor mannen en vrouwen geschikt acht in het gezinsleven, in de politiek, wat betreft leiderschap, in het onderwijs, in de zorg voor kinderen en op de arbeidsmarkt. We hebben één van deze domeinen onderzocht: de impact van het werken van de vrouw op het gezinsleven, hier benoemd als traditionele vrouwenrollen. De respondenten kregen vijf stellingen die ze konden beantwoorden met helemaal mee eens, mee eens, noch eens/noch oneens, oneens, helemaal niet mee eens. De items zijn zodanig getransformeerd dat een hogere score een grotere steun uitdrukt voor traditionele vrouwenrollen.

1. Een werkende moeder kan net zo'n warme en zekere relatie opbouwen met haar kinderen als een moeder die niet werkt.

2. Een kind dat nog niet naar school gaat, lijdt er waarschijnlijk onder wanneer zijn of haar moeder werkt.

3. Het gezinsleven heeft er in het algemeen onder te lijden wanneer de vrouw fulltime betaald werk verricht.

4. Een baan is prima, maar wat vrouwen echt willen is een thuis en kinderen.

5. Huisvrouw zijn is net zo bevredigend als een betaalde baan.

We hebben een confirmatieve factoranalyse uitgevoerd, waarbij gebruik gemaakt is van LISREL en JRule (Saris, Satorra \& Van der Veld, 2009) om te toetsen in hoeverre ons meetmodel gelijk is tussen landen. Er worden drie typen meetequivalentie onderscheiden (Van der Veld \& Saris, 2010): 'configural' (gelijk factor model), 'metric' (gelijke factor ladingen) en 'scalar invariance' (gelijke intercepten van de latente constructen). Wanneer alle drie gelden, kunnen we de gemiddelden tussen de

Figuur 1 Meetmodel voor 'traditionele vrouwenrollen'

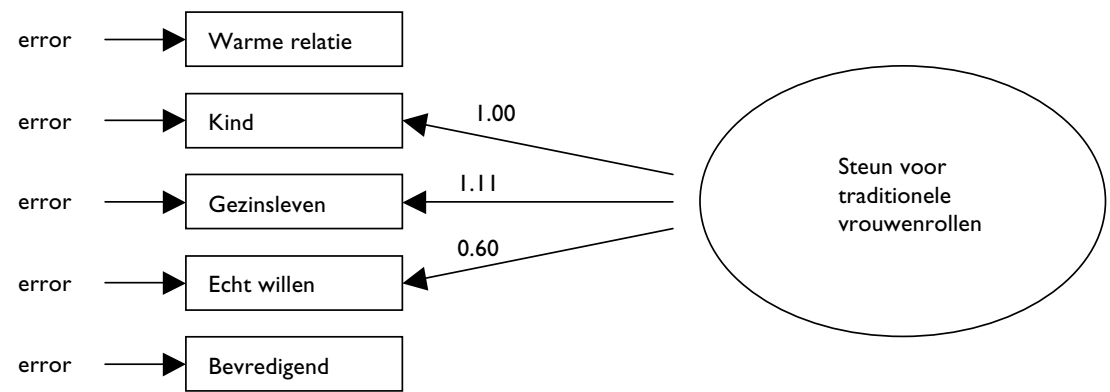

Noot: De ongestandaardiseerde factorladingen zijn weergegeven. 
landen betekenisvol vergelijken. Het blijkt dat het initiële factor model, met alle vijf indicatoren, niet correct is. We hebben het item 'bevredigend' verwijderd vanwege de lage factorladingen (lager dan 0.20 in alle landen), hetgeen erop wijst dat dit item het beoogde concept, namelijk steun voor traditionele vrouwenrollen niet betrouwbaar en valide meet in al deze landen. We hebben ook de stelling 'relatie' verwijderd, omdat dit item in alle Oost-Europese landen een lage factorlading had, hetgeen betekent dat dit item niet relevant is voor onze schaal in die landen. Een mogelijke verklaring hiervoor is dat er in de tijd van volledige werkgelegenheid onder het communisme officieel geen 'huisvrouwen' waren in de Oost-Europese landen en dat dit beleid nog terug te zien is in de houdingen van de mensen. Het overblijvende meetmodel gebaseerd op drie items, is configural invariant, het is tevens 'metric' invariant en deels scalar invariant in 32 landen (hetgeen betekent dat er in een aantal landen 'correlated errors' toegevoegd zijn) volgens JRule, een programma dat relevante misspecificaties opspoort in meetmodellen (Saris, Satorra \& Van der Veld, 2009). Het model was niet 'metric' en 'scalar' invariant in Brazilië en Taiwan en het was niet 'scalar' invariant in Finland. ${ }^{2}$ Daarom kunnen we de scores van Brazilië, Taiwan en Finland niet meenemen, want die zijn strikt genomen niet vergelijkbaar. De RMSEA van dit model in 32 landen is 0,088 , hetgeen acceptabel is (MacCullum, Browne \& Sugawara, 1996). De uitkomst dat slechts drie van de vijf items gebruikt kunnen worden voor het over de landen vergelijkbare meetmodel, impliceert dat onze uitkomsten anders kunnen zijn dan eerdere crossnationale onderzoeken, waarin alle items in de ISSP zijn gebruikt (Van der Veld $\&$ Saris, 2010). We hebben voor de verdere analyses over deze drie items een gemiddelde score per persoon berekend in de 32 landen, die (deels) 'scalar' invariant waren. Dit betekent dat de score van een respondent op de afhankelijke variabele kan variëren tussen 1 en 5.

\subsection{Onafhankelijke variabelen op individueel niveau}

De meeste variabelen zijn dummy variabelen, behalve cohort, het aantal kinderen en het bezoeken van religieuze diensten. Deze laatstgenoemde variabelen zijn gecentreerd op het grootte gemiddelde alvorens ze op te nemen in onze regressiemodellen. Voor de variabele sekse hebben we vrouwen als referentiecategorie gebruikt. Tevens is gecodeerd of de respondent een werkende moeder had voor het $14 \mathrm{e}$ jaar (ja/nee) en wat het geboortejaar is van de respondent. Opleidingsniveau is gecodeerd met zes dummies: basisschool (inclusief geen opleiding), lager secundair onderwijs (inclusief incompleet), hoger secundair onderwijs (afgerond), meer dan hoger secundair onderwijs, universiteit, en een aparte categorie voor ontbrekende waarden. Arbeidsstatus werd gemeten met 
acht dummy's: werkloos, student, huisvrouw, werkt minder dan 15 uur, 15 tot 34 uur, meer dan 34 uur, anders niet-werkend en ontbrekende waarden. Burgerlijke staat is geoperationaliseerd met vier dummy's: alleenstaand, getrouwd/samenwonend, weduwe/weduwnaar en gescheiden. Het aantal kinderen loopt uiteen van 0 tot en met 9 (meer dan 9 kinderen werd gecodeerd als 9). Denominatie bestaat uit geen religie, katholiek, protestant, orthodox, joods, islamitisch, oosterse religies en andere religies. Het bezoek van religieuze diensten werd gecodeerd van (0) gaat nooit naar de kerk tot (7) gaat meerdere keren per week naar de kerk. We hebben het inkomen van de respondent per land in kwartielen gecodeerd: laag inkomen, laag tot midden inkomen, midden tot hoog inkomen en hoog inkomen. Zij die geen geldig antwoord hadden voor inkomen kregen een (1) voor de variabele ontbrekende waarden. Urbanisatiegraad telt vijf dummy's: stedelijk, voorstedelijk, kleine stad, dorp en platteland.

\subsection{Onafhankelijke variabelen op contextueel niveau}

We hebben de gezinsbeleidmodellen geoperationaliseerd met zes dummy's. De categorisering is voornamelijk gebaseerd op eerder onderzoek naar gezinsbeleidmodellen (Boye, forthcoming; Ferrarini \& Sjöberg, forthcoming; Korpi, 2000; Panayatova \& Brayfield, 1997), waarin men uitging van het niveau van steun voor het traditionele gezin (beleid gebaseerd op het idee van de familie als hoeksteen van de samenleving) en het niveau van steun voor het gezin met tweeverdieners (beleid gebaseerd op het idee dat beide partners de mogelijkheid moeten hebben om te werken). Voor meer informatie refereren we naar Korpi (2000). Denemarken, Noorwegen en Zweden vallen onder het 'tweeverdienermodel'; Oostenrijk, België, Frankrijk, Duitsland en Nederland onder 'het traditionele model'; Ierland, Zwitserland, de Verenigde Staten en het Verenigd Koninkrijk onder 'het marktgeoriënteerde model'; en de Oost-Europese landen onder 'het tegenstrijdige model'. Hoewel er wordt gezegd dat de indeling op basis van gezinsbeleidmodel beter is ten opzichte van de verzorgingsstaatstypologie (Guo \& Gilbert, 2007; Korpi, 2000), blijkt dat de landen zoals deze door Esping-Andersen (1990) werden gecategoriseerd, op een vergelijkbare manier worden geclusterd in de gezinsbeleidmodellen. Echter, een voordeel van het gezinsbeleidmodel is dat er meer landen kunnen worden opgenomen in de typologie. Maar negen landen waren nog niet eerder gecategoriseerd. Om deze landen in de analyse te houden stellen we voor om ze in twee categorieën onder te verdelen. We stellen voor om Spanje, Portugal en Cyprus onder het 'mediterrane model' te scharen, aangezien het mediterrane welvaartsstaten zijn (Kääriäinen \& Lehtonen, 2006; Scheepers \& Te Grotenhuis, 2005). De overige 
landen (Chili, Mexico, de Filippijnen en Israël) werden gecategoriseerd als 'overig'. Onze categorisering in zes groepen is vrij goed en geeft homogene groepen. De variantie tussen groepen $(3.31, \mathrm{df}=6)$ is groter dan de variantie binnen groepen $(1.00, \mathrm{df}=25)$ en dit verschil is significant $(\mathrm{F}=13.7, \mathrm{p}=0.00)$. Alleen de 'mediterrane' landen blijken geen homogene groep te vormen.

\subsection{Analysestrategie}

Eerst wordt de mate van steun voor traditionele vrouwenrollen beschreven in tabel 1. Daarna gebruiken we random intercept en random slope multiniveau-analyse om onze verklaringen voor de steun voor traditionele vrouwenrollen te onderzoeken. Multiniveau-analyse is de geschiktste methode voor de analyse van geneste data (Snijders \& Bosker, 1999). In onze analyse is het land het hoogste niveau (niveau 2) waarin respondenten (niveau 1) zijn genest. De hiërarchische modellen worden in SPSS geschat. Een tweede reden om multiniveau-analyse toe te passen is omdat we twee soorten verklaringen onderzoeken; op landniveau en individueel niveau. Om deze verklaringen correct te onderzoeken en om hun aparte en gezamenlijke effecten vast te stellen is het aangewezen om multiniveau-analyse toe te passen. We onderzoeken eerst de individuele verklaringen en presenteren de relevante resultaten in tabel 2 , waarna we de resultaten voor de contextuele en 'crosslevel'-verklaringen presenteren in tabel 3.

\section{Resultaten}

In tabel 1 presenteren we de gemiddelde scores voor de steun voor traditionele vrouwenrollen in 2002, gevolgd door de scores van vrouwen, mannen en de verschillen tussen de seksen. Hogere scores betekenen meer steun (de schaal loopt van 1 tot 5). Uit tabel 1 blijkt dat er sterke verschillen zijn tussen landen in de steun voor traditionele vrouwenrollen. De meeste steun vinden we in Chili $(2,85)$, Mexico $(2,76)$ en Hongarije $(2,67)$ en de minste in Zweden $(1,55)$, Oost-Duitsland $(1,44)$ en Denemarken $(1,43)$.

Om onze eerste vraag te beantwoorden is het verschil tussen mannen en vrouwen voor de steun voor traditionele vrouwenrollen berekend door het gemiddelde van de mannen in een land af te trekken van het gemiddelde van de vrouwen in datzelfde land. Een positieve score in tabel 1 betekent dus dat vrouwen de traditionele vrouwenrollen meer steunen dan mannen, terwijl een negatieve score duidt op een grotere mate van steun onder de mannen. We zien dat in de meeste van de 32 landen vrouwen minder steun betuigen aan traditionele vrouwenrollen dan 
Tabel 1 Gemiddelde mate van steun voor traditionele vrouwenrollen (1-5) binnen landen en sekseverschillen.

292

\begin{tabular}{|c|c|c|c|c|c|}
\hline & 2002 & Vrouw & Man & Verschil & $\mathbf{N}$ \\
\hline Australië & 1,96 & 1,79 & 2,07 & $-0,28^{*}$ & 1352 \\
\hline Oostenrijk & 2,31 & 1,89 & 2,08 & $-0,19 *$ & 2047 \\
\hline Bulgarije & 2,51 & 2,32 & 2,40 & $-0,08$ & 1003 \\
\hline Chili & 2,85 & 2,56 & 2,56 & 0,00 & 1505 \\
\hline Cyprus & 1,86 & 1,63 & 1,76 & $-0,13^{*}$ & 1004 \\
\hline Tsjechië & 2,31 & 1,95 & 2,05 & $-0,10^{*}$ & 1289 \\
\hline Denemarken & 1,43 & 1,34 & 1,50 & $-0,16 *$ & 1379 \\
\hline Vlaanderen & 2,11 & 1,99 & 2,15 & $-0,16^{*}$ & 1360 \\
\hline Frankrijk & 2,00 & 1,68 & 1,95 & $-0,27^{*}$ & 1903 \\
\hline Duitsland (oost) & I,44 & 1,10 & 1,32 & $-0,22^{*}$ & 936 \\
\hline Duitsland (west) & 1,97 & $\mid, 61$ & 1,88 & $-0,27^{*}$ & 431 \\
\hline Groot-Brittannië & 1,85 & 1,75 & 1,94 & $-0,19 *$ & 1960 \\
\hline Hongarije & 2,67 & 2,34 & 2,30 & 0,04 & 1023 \\
\hline lerland & 1,83 & I,76 & 1,97 & $-0,21 *$ & 1240 \\
\hline Israël & 2,12 & I,79 & 1,95 & $-0,16 *$ & 1209 \\
\hline Japan & 1,84 & 1,88 & 1,85 & 0,03 & 1132 \\
\hline Letland & 2,39 & 2,11 & 2,13 & $-0,02$ & 1000 \\
\hline Mexico & 2,76 & 2,49 & 2,40 & $0,09 *$ & 1495 \\
\hline Nederland & 2,00 & 1,76 & 1,89 & $-0,13^{*}$ & 1249 \\
\hline Nieuw-Zeeland & 1,95 & ।,88 & 2,02 & $-0,14 *$ & 1025 \\
\hline Noord-lerland & 1,98 & 1,88 & 1,97 & $-0,09$ & 987 \\
\hline Noorwegen & 1,59 & 1,48 & 1,68 & $-0,20 *$ & 1475 \\
\hline Filippijnen & 2,37 & 2,26 & 2,21 & 0,05 & 1200 \\
\hline Polen & 2,23 & 2,05 & 2,19 & $-0,14 *$ & 1252 \\
\hline Portugal & 2,58 & 2,28 & 2,36 & $-0,08$ & 1092 \\
\hline Rusland & 2,53 & 2,20 & 2,21 & $-0,01$ & 1798 \\
\hline Slowakije & 2,52 & 2,09 & 2,23 & $-0,14 *$ & 1133 \\
\hline Slovenië & 2,32 & 2,02 & 2,11 & $-0,09$ & 1093 \\
\hline Spanje & 2,12 & 1,91 & 2,02 & $-0,11 *$ & 2471 \\
\hline Zweden & 1,55 & 1,45 & 1,65 & $-0,20 *$ & 1080 \\
\hline Zwitserland & 2,19 & 1,94 & 2,09 & $-0,15^{*}$ & 1008 \\
\hline Verenigde Staten & I,82 & 1,73 & 1,99 & $-0,26 *$ & 1171 \\
\hline Totaal & & & & & 40696 \\
\hline
\end{tabular}

$*$ = significant verschil tussen mannen en vrouwen, $p<0.05$

Bron: ISSP 2002, eigen berekeningen 
mannen. In Bulgarije, Chili, Hongarije, Japan, Letland, Noord-Ierland, de Filippijnen, Portugal, Rusland, Slovenië en Taiwan bleek dat de sekseverschillen in steun voor traditionele vrouwenrollen niet significant zijn. Alleen in Mexico waren de vrouwen traditioneler ingesteld dan de mannen. In het multiniveaumodel is het effect van geslacht ook significant verschillend tussen de 32 onderzochte landen, de random slope was $(b=0.01, p=0.002)$.

In tabel 2 presenteren we de bevindingen van de individuele kenmerken in relatie tot steun voor traditionele vrouwenrollen. Hiermee beantwoorden we het eerste deel van onze tweede onderzoeksvraag. Het eerste model in tabel 2 is het nulmodel, dat alleen een random intercept bevat, hetgeen inhoudt dat de gemiddelde scores van landen voor de mate van steun voor traditionele vrouwenrollen van elkaar kunnen verschillen. De variantie op individueel niveau $(0,860)$ is groter dan op het landniveau $(0,134)$. De intraklassecorrelatie is 0,135 . Het intercept $(3,12)$ is de gemiddelde steun voor traditionele vrouwenrollen berekend voor alle 32 landen samen. In model 1 voegen we alle individuele kenmerken toe die betrekking hebben op onze hypotheses en in model 2 presenteren we vervolgens de effecten van deze variabelen, maar dan gecontroleerd voor de controlevariabelen. Na toevoeging van de individuele determinanten van de steun voor traditionele vrouwenrollen verbetert de fit met 5307 punten in model 1 , hetgeen significant is. We vinden een reductie van de individuele variantie van 12 procent en van de landenvariantie van 13 procent. Door het toevoegen van de extra (controle) variabelen veranderen de varianties en de effecten van de individuele kenmerken nauwelijks. We gebruiken daarom model 2 voor de empirische toets van onze hypothesen.

In tabel 2 zien we in de eerste plaats dat mannen, gemiddeld genomen, meer steun betuigen voor traditionele vrouwenrollen dan vrouwen $(0,19)$. Dit is in lijn met het idee van differentiële socialisatie (Stark, 2004). Hij stelde dat mannen en vrouwen verschillend worden gesocialiseerd en dit is te zien in de houdingen die mannen en vrouwen gemiddeld genomen hebben. Onze cohorthypothese en werkende-moederhypothese zijn bevestigd. We constateren dat respondenten, wier moeder in hun jeugd werkte, traditionele vrouwenrollen minder steunen $(-0,14)$ dan respondenten die een niet-werkende moeder hadden. Jongere cohorten hebben ook minder voorkeur voor traditionele vrouwenrollen: elke toename in het geboortejaar resulteert in een afname van 0,01 op de afhankelijke variabele. Onze opleidingshypothese is eveneens bevestigd. Voor elke groep hoger opgeleide respondenten zien we dat zij traditionele vrouwenrollen minder steunen dan de laagst opgeleide respondenten, en dat verschil neemt toe. Dit suggereert dat hoe langer mensen worden gesocialiseerd in het opleidingssysteem, des te minder zij traditio- 
Tabel 2 Individuele determinanten van de steun voor traditionele vrouwenrollen $(\mathrm{N}=40696)$

\begin{tabular}{|c|c|c|c|}
\hline & Model 0 & $\begin{array}{l}\text { Model I } \\
\text { Zonder contro- } \\
\text { le variabelen }\end{array}$ & $\begin{array}{l}\text { Model } 2 \\
\text { Met controle } \\
\text { variabelen }\end{array}$ \\
\hline Intercept & $3,12^{\text {**** }}$ & $3,4 I^{* * * * *}$ & $3,38^{* * * *}$ \\
\hline Man & & 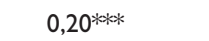 & 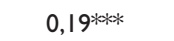 \\
\hline \multicolumn{4}{|l|}{ Jeugd } \\
\hline Werkende moeder & & $-0,15^{* * * *}$ & $-0,14 * * *$ \\
\hline Geboortejaar (gecentreerd) & & $-0,01 * * * k$ & $-0,01 * * *$ \\
\hline \multicolumn{4}{|l|}{ Opleiding } \\
\hline \multicolumn{4}{|l|}{ Primair $=$ ref } \\
\hline Secundair (onafgerond) & & $-0,07^{* * * *}$ & $-0,07^{* * * *}$ \\
\hline (Hoger) secundair (afgerond) & & $-0,18^{* * * k}$ & $-0,17^{* * * k}$ \\
\hline Meer dan hoger secundair & & $-0,28 * * *$ & $-0,26 * * *$ \\
\hline Universiteit & & $-0,46 * * * k$ & $-0,44^{* * * *}$ \\
\hline Ontbrekend & & $-0,08 *$ & $-0,09 *$ \\
\hline \multicolumn{4}{|l|}{ Arbeidssituatie } \\
\hline \multicolumn{4}{|l|}{ Huisvrouw/man (= ref) } \\
\hline Niet-werkzaam anderszins & & $-0,15 * * *$ & $-0,15 * * *$ \\
\hline Werkloos & & $-0,18^{* * * *}$ & $-0,19 * * * *$ \\
\hline Student & & 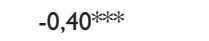 & $-0,42 * * * *$ \\
\hline Werkt $<15$ uur per week & & $-0,14^{* * * *}$ & $-0,14 * * * *$ \\
\hline Werkt 15-34 uur per week & & $-0,28^{* * * *}$ & $-0,27^{* * * *}$ \\
\hline Werkt $>34$ uur per week & & $-0,33^{* * *}$ & $-0,32 * * *$ \\
\hline Ontbrekend & & $-0,18^{* * * *}$ & $-0,19 * * *$ \\
\hline \multicolumn{4}{|l|}{ Familie } \\
\hline \multicolumn{4}{|c|}{ Burgerlijke status (alleenstaand $=$ ref) } \\
\hline Gehuwd & & $0,04^{* *}$ & $0,09 * * *$ \\
\hline Verweduwd & & 0,03 & 0,03 \\
\hline Gescheiden & & 0,02 & 0,02 \\
\hline Aantal kinderen (gecentreerd) & & $0,01 * *$ & $0,01 * *$ \\
\hline \multicolumn{4}{|l|}{ Religieuze denominatie } \\
\hline \multicolumn{4}{|l|}{ Geen (= ref) } \\
\hline Katholiek & & $0,10^{* * * * k}$ & 0,10 **** \\
\hline Protestant & & $0,09 * * * *$ & $0,09 * * *$ \\
\hline Orthodox & & 0,16 **⿰冫⿰亅⿱丿丶丶 & $0,16 * * *$ \\
\hline Joods & & 0,01 & 0,01 \\
\hline Islamitisch & & $0,27^{* * * *}$ & $0,26 * * *$ \\
\hline Oosterse religie & & 0,13 & 0,15 \\
\hline Andere religie & & $0,23 * * * *$ & $0,22 * * *$ \\
\hline Kerkgang (gecentreerd) & & $0,03^{* * * * k}$ & $0,03^{* * * k}$ \\
\hline-2 log likelihood & 109517 & 104210 & 104067 \\
\hline Verandering in fit & 0 & $5307 * * * *$ & $5450 * * *$ \\
\hline Individuele variantie & 0,860 **** & $0,755^{* * * *}$ & $0,752^{* * * *}$ \\
\hline Landen variantie & $0,134^{* * * * *}$ & $0,116^{* * * *}$ & $0,113 * * *$ \\
\hline
\end{tabular}

**** $p<0.001 * * p<0.01 * p<0.05$

Bron: ISSP 2002, eigen berekeningen

Noot.Alle veranderingen in fit zijn significant en getoetst met een Chi kwadraat verdeling en de bijbehorende verandering in vrijheidsgraden, afgezet tegen het nul-model. 
nele vrouwenrollen steunen. De arbeidshypothese is gedeeltelijk bevestigd, omdat niet alle niet-werkende categorieën significant afwijken van de werkende categorieën (getoetst met de categorieën huisvrouw (weergegeven), niet-werkzaam en werkloos (niet weergegeven)). We gebruiken huisvrouwen als referentiecategorie, aangezien zij theoretisch gezien de traditioneelste rol vervullen. We zien inderdaad dat zij de traditioneelst ingestelde sociale groep zijn. Ook blijkt dat respondenten in de categorie 'niet-werkzaam anderszins', 0,15 punten minder traditioneel ingesteld zijn dan huisvrouwen en dat werklozen (die in principe eerder werk hebben gehad en dus ooit zijn gesocialiseerd op de werkvloer) 0,19 minder traditioneel zijn dan huisvrouwen. De werkende respondenten hebben ook een lagere mate van traditionaliteit dan huisvrouwen. Bovendien wordt het verschil groter bij een hoger aantal gewerkte uren. Tot slot zien we dat studenten traditionele vrouwenrollen het minste steunen. Echtparen laten, zoals verwacht, meer steun zien dan alleenstaanden $(0,09)$, terwijl weduwen of gescheiden respondenten niet verschillen ten opzichte van alleenstaande respondenten. Het aantal kinderen heeft het verwachte positieve effect $(0,01)$ : dit betekent dat hoe meer kinderen mensen hebben, des te meer zij traditionele vrouwenrollen steunen. Dit bevestigt onze gezinshypothese. Onze religiehypothese bestond uit twee delen. Ten eerste stelden we dat religieuzen en niet-religieuzen verschilden. Dit is bijna altijd het geval: alleen joden en volgelingen van oosterse religies verschillen niet significant van niet-religieuze respondenten. Daarom wordt deze hypothese slechts ten dele bevestigd. We stelden tevens dat sommige religies meer steun betuigen voor traditionele vrouwenrollen dan andere. We zien dat moslims de meeste steun uitspreken $(0,26)$ vergeleken met niet-religieuze mensen, gevolgd door aanhangers van 'andere religies' $(0,22)$, orthodoxen $(0,16)$, katholieken $(0,10)$ en protestanten $(0,09)$. Dit is in lijn met onze verwachting dat moslims de meeste steun betuigen en joden de minste. Daarnaast stelden we dat een sterkere integratie in de religieuze gemeenschap leidt tot een hogere mate van steun. Dit klopt: naarmate mensen vaker religieuze diensten bezoeken, volgen zij des te meer de norm van traditionele vrouwenrollen. Daarom bevestigen wij onze religieuze-integratiehypothesen.

Tabel 3 bevat twee modellen die informatie bevatten om het tweede deel van onze tweede onderzoeksvraag te beantwoorden. De fit van elk model wordt vergeleken met het model met alle individuele determinanten (model 2 van tabel 2). Met de resultaten in het eerste model in tabel 3 komen we tot een toetsing van de contextuele verklaringen. Het traditionele gezinsbeleidmodel is de referentiecategorie. We zien dat het enige beleidsmodel dat significant 'negatief' verschilt van het traditionele gezinsbeleidmodel, het tweeverdienersmodel is. Dit steunt onze hypothese, aangezien dit model het sterkst verschilt van het traditionele 
Tabel 3 De invloed van contextuele kenmerken op steun voor traditionele vrouwenrollen, inclusief interacties $(\mathrm{N}=40696)$

\begin{tabular}{|c|c|c|}
\hline & Model I & Model 2 \\
\hline Intercept & 2,21 *** & $2,20 * * * *$ \\
\hline Man (fixed) & $0,16 * * * *$ & $0,22 * * * *$ \\
\hline Man (random) & $-0,01 * * *$ & 0,00 \\
\hline \multicolumn{3}{|l|}{ Beleidsmodellen } \\
\hline \multicolumn{3}{|l|}{ Traditioneel (= ref) } \\
\hline Marktgeoriënteerd & $-0,09$ & $-0,09$ \\
\hline Mediterraan & 0,14 & 0,14 \\
\hline Tegenstrijdig & $0,58 * * *$ & $0,56 * * * *$ \\
\hline Tweeverdieners & $-0,31 *$ & $-0,3 I^{*}$ \\
\hline Anders & $0,55^{* * * *}$ & $0,56 * * * *$ \\
\hline Marktgeoriënteerd*man & & 0,03 \\
\hline Mediterraan*man & & $-0,05$ \\
\hline Tegenstrijdig*man & & $-0,14 * * * *$ \\
\hline Tweeverdieners*man & & 0,01 \\
\hline Anders*man & & $-0,19 * * * *$ \\
\hline-2 log likelihood & 103963 & 103932 \\
\hline Verandering in fit & $104 * * *$ & $135 * * *$ \\
\hline Individuele variantie & $0,752 * * * *$ & $0,750 * * * * *$ \\
\hline Landen variantie & $0,037 * * *$ & $0,035^{* * * *}$ \\
\hline
\end{tabular}

*** $p<0.001 * * p<0.01 * p<0.05$

Bron: ISSP 2002, eigen berekeningen

Noot. In alle modellen zijn alle individuele kenmerken meegenomen als controlevariabelen. De significantie van de verandering in fit is verkregen door het betreffende model te vergelijken met model 2 in tabel 2.

model wat betreft de maatschappelijke positie van vrouwen. Mensen die leven in een land waar het beleid is gericht op tweeverdieners, scoren 0,31 punten lager op de steun voor traditionele vrouwenrollen dan mensen die leven in een land waarin het traditionele gezinsmodel wordt gestimuleerd, onafhankelijk van individuele kenmerken. Vervolgens zien we dat mensen die leven in landen met tegenstrijdig gezinsbeleid significant meer steun laten zien voor traditionele vrouwenrollen $(0,58)$ dan mensen in landen met traditioneel beleid. Dit is een weerlegging van onze hypothese. Een mogelijke verklaring is dat vrouwen in deze landen, in de dagen van het communisme, voltijd werk moesten combineren met het huishouden en dat 'alleen' moeder kunnen zijn als een luxe werd gezien (Panayatova \& Brayfield, 1997). Deze luxe werd mogelijk na de val van het IJzeren Gordijn, wat meer steun voor traditionele vrouwenrollen teweegbracht. Dit betekent dat onze hypothese over de invloed van gezinsbeleid gedeeltelijk is bevestigd, en dat de resultaten 
in landen met een tegenstrijdig gezinsbeleid strijdig zijn met hetgeen wij hadden verwacht. Bovendien zien we dat er geen verschillen zijn in steun voor traditionele vrouwenrollen tussen respondenten die in landen leven met een marktgeoriënteerd model of een Mediterraan model, vergeleken met mensen die leven in landen met een traditioneel gezinsbeleidmodel (referentie). Bovendien vinden we dat mensen die in de landen met een 'ander' gezinsbeleid leven, meer steun laten zien voor traditionele vrouwenrollen dan mensen die wonen in een land met een traditioneel gezinsbeleid.

In het tweede model in tabel 3 onderzoeken we, ter beantwoording van onze derde onderzoeksvraag, de crosslevel-interacties van het gezinsbeleid van een land met geslacht op individueel niveau. In onze crosslevel-interactiehypothese stelden we dat in landen met gezinsbeleid dat zich richt op tweeverdieners, het verschil tussen mannen en vrouwen in de steun voor traditionele vrouwenrollen kleiner zou zijn dan in landen met een traditioneel beleidsmodel. Echter, het niet significante crosslevel interactie effect (voor 'tweeverdiener' * 'mannelijk') laat zien dat onze hypothese verworpen moet worden. Ofschoon het niveau van steun voor traditionele vrouwenrollen lager is in landen met tweeverdienersbeleid, is er een vergelijkbaar niet-significant verschil tussen de seksen in die landen die gericht zijn op het stimuleren van tweeverdienerhuishoudens als in landen waar arbeidsparticipatie van vrouwen wordt geremd en de nadruk ligt op de zorgtaken van vrouwen.

We zien echter wel twee andere significante crosslevel-interacties. Dit is het geval voor de landen die behoren tot het 'tegenstrijdige' en het 'andere' gezinsbeleid. In deze landen is het gemiddelde niveau van steun hoger vergeleken met het traditionele model, maar is het verschil tussen de seksen significant kleiner dan in traditionele landen: de crosslevelinteracties zijn immers negatief (respectievelijk -0,16 en -0,17) en significant. Dit betekent dat mannen en vrouwen meer op elkaar lijken in de landen die er tegenstrijdig en 'ander' gezinsbeleid op nahouden, dan in landen met een traditioneel gezinsbeleid. Omdat het hier om de landen gaat waar de gemiddelde mate van steun voor traditionele rollen het hoogst is, duidt deze bevinding erop dat in de meest traditionele landen mannen en vrouwen ook de meeste overeenkomsten vertonen in hun houding ten opzichte van de rol die vrouwen dienen te vervullen in de maatschappij.

\section{Conclusie en discussie}

In dit onderzoek hebben we geprobeerd antwoord te geven op drie onderzoeksvragen die de steun voor traditionele vrouwenrollen centraal stellen. Om antwoord te krijgen hebben we hypothesen afgeleid uit de 
socialisatie- en rationele-keuzetheorie en hebben we aandacht besteed aan differentiële effecten voor mannen en vrouwen. Bovendien hebben we de vergelijkbaarheid van ons meetmodel tussen landen onderzocht. We ontdekten dat twee van de vijf items die vaak worden gebruikt in het onderzoek naar steun voor traditionele vrouwenrollen (Brooks \& Bolzendahl, 2004; Panayatova \& Brayfield, 1997; Sjöberg, 2004) niet konden worden gebruikt voor een betekenisvolle vergelijking tussen deze landen. Voor 32 van de 35 landen bleek het meetmodel gebaseerd op drie items crossnationaal vergelijkbaar.

Uit ons onderzoek blijkt dat steun voor traditionele vrouwenrollen het hoogst is in Chili en het laagst in Denemarken. Over het algemeen zagen we dat vrouwen traditionele vrouwenrollen minder steunen dan mannen. Na deze beschrijving richtten we ons op het verklaren van verschillen tussen individuen en tussen landen. Onze onderzoeksvraag luidde: in hoeverre kunnen verschillen in steun voor traditionele vrouwenrollen in 2002 worden verklaard met individuele en contextuele eigenschappen? We hebben steun gevonden voor de cohorthypothese en werkende-moederhypothese: respondenten die tot jongere cohorten behoren en die zijn opgevoed door werkende moeders, betuigden minder steun voor traditionele vrouwenrollen, zoals ook uit eerder onderzoek bleek (Banaszak \& Plutzer, 1993; Bolzendahl \& Myers, 2004; Motiejunaite \& Kravchenko, 2008). De opleidingshypothese vond geheel en de arbeidshypothese vond gedeeltelijk ondersteuning: hoger opgeleiden en personen die meer dan 15 uur per week werkten, bleken minder traditioneel ingesteld dan lager opgeleiden en niet-werkzamen. Ook de gezinshypothese werd bevestigd, omdat getrouwde mensen en mensen met meer kinderen blijk gaven van meer steun voor traditionele vrouwenrollen. Dit komt overeen met de meeste, eerdere bevindingen (Bolzendahl \& Myers, 2004; Davis \& Robinson, 1991; Penn \& Lambert, 2002). Religiositeit en religieuze integratie bleken eveneens belangrijke determinanten: niet-religieuzen en mensen die niet deelnemen aan religieuzen diensten bleken het minst traditioneel met betrekking tot de rol van de vrouw. Dit bevestigde grotendeels onze verwachtingen en eerdere bevindingen (Brooks \& Bolzendahl, 2004; Carter, Corra \& Carter, 2009; Motiejunaite \& Kravchenko, 2008). De bevindingen sluiten aan bij ons theoretische raamwerk, omdat socialisatie in een traditioneel sociaal milieu, in het opleidingssysteem, in de beroepsbevolking en in een religieus instituut de houding van individuen over traditionele vrouwenrollen beïnvloedt. We kunnen echter geen strikte conclusie trekken over de causaliteit van de gevonden relaties. Zo veronderstelden we bijvoorbeeld dat deelname aan de arbeidsmarkt de houdingen beïnvloedt, maar het is waarschijnlijk ook zo dat mensen met niet-traditionele houdingen vaker werken. Voor dit type uitspraken zijn longitudinale paneldata nodig. Voor grootschalige crossnationale studies is dit type gegevens vooralsnog niet beschikbaar. 
Op het contextuele niveau hebben we gezien dat gezinsbeleidmodellen (Ferrarini, 2006; Korpi, 2000; Sjöberg 2004) verschillen in de steun voor traditionele vrouwenrollen kunnen verklaren tussen landen en tussen individuen. In landen waarin beleid hoofdzakelijk is gericht op het stimuleren van arbeidsparticipatie onder vrouwen en moeders - het tweeverdienermodel - steunen mensen traditionele vrouwenrollen het minst. Dit is in lijn met eerdere bevindingen van Sjöberg (2004). Echter, wij waren in staat deze conclusie te baseren op een groter en diverser aantal landen, waarbij we gebruik maakten van een schaal gebaseerd op drie items, die invariant bleek over 32 landen. Ook hier kunnen we niet zeker zijn wat betreft de causaliteit. We denken dat het een 'bottom-up' proces is, waarin de houdingen van mensen zoals uitgedrukt in de voorkeuren tijdens de verkiezingen, het beleid beïnvloeden zoals dat in een land gestalte krijgt. We verwachten echter ook dat dit soort beleid op haar beurt bepaalde houdingen naar traditionele vrouwenrollen afdwingt en versterkt. Of dit het geval is, zou onderzocht moeten worden met longitudinale data. Vervolgonderzoek zou zich ook kunnen richten op een betere indeling van het gezinsbeleid zoals dat zich ontwikkeld heeft in Oost-Europese landen en landen buiten Europa.

Dat vrouwen over het algemeen minder steun betuigen aan traditionele vrouwenrollen dan mannen, komt overeen met eerder onderzoek (Amato \& Booth, 1995; Berridge, Penn \& Ganjali 2009; Bolzendahl \& Myers, 2004; Carter, Corra \& Carter, 2009; Cassidy \& Warren, 1996; Cherlin \& Walters, 1981; Gibbons, Hamby \& Dennis 1997; Harris \& Firestone, 1998; Mason \& Lu, 1988). Met de beantwoording van onze laatste onderzoeksvraag, in hoeverre verschillen contextuele verklaringen voor de steun voor traditionele vrouwenrollen voor mannen en vrouwen?, kwamen we tot nieuwe inzichten. We vonden dat de verschillen in steun tussen mannen en vrouwen significant variëren tussen landen. Dit impliceert dat de verschillende nationale contexten waaraan men kan worden blootgesteld, de steun voor traditionele vrouwenrollen ook op verschillende wijze beïnvloeden (in tegenstelling tot wat wordt verondersteld door Sjöberg (2004)). Onze bevindingen wijzen uit dat de sekseverschillen niet significant kleiner zijn in landen met een tweeverdienermodel dan in landen waarin beleid juist traditionele vrouwenrollen versterkt. Hierdoor moest onze hypothese worden verworpen. Deze bevinding impliceert dat in maatschappijen waarin men met beleid seksegelijkheid promoot, de algemene steun voor gelijkheid hoger is, maar dat niettemin in zulke maatschappijen de verschillen tussen mannen en vrouwen vergelijkbaar zijn waar het gaat om de voorkeur die men heeft voor traditionele vrouwenrollen. Het gaat hier echter om ontwikkelde, doorgaans Europese landen, die, of ze nu traditioneel of progressief zijn waar het gaat om vrouwenemancipatie, relatief weinig steun verlenen aan traditionele vrouwenrollen. 
We zagen daarentegen wel dat in landen met een tegenstrijdig, of niet nader omschreven (ander) gezinsbeleid, de sekseverschillen significant kleiner zijn. Landen die we hebben geplaatst in het 'andere' gezinsbeleidmodel, zijn landen als Chili, Mexico en de Filippijnen. Dit zijn de landen in onze dataset die het minst ontwikkeld zijn en die ook in het algemeen de minste mate van vrouwenemancipatie laten zien. Dat zowel mannen als vrouwen in deze landen veel steun betuigen aan traditionele vrouwenrollen, duidt op een grote overeenkomst tussen de seksen over de rol van de vrouw in de maatschappij. De vraag is wat er met de sekseverschillen gebeurt wanneer deze landen zich ontwikkelen en daarmee, mogelijk meer emanciperen. We veronderstellen dat in landen met tegenstrijdig gezinsbeleid, de nadruk op steun voor het traditionele gezin zwaarder weegt dan de - tegengestelde - nadruk op het tweeverdienerprincipe. In deze landen waar de nadruk op traditioneel gezinsbeleid blijkbaar stand heeft gehouden, is de algemene steun voor traditionele vrouwenrollen hoger en zijn de verschillen tussen mannen en vrouwen kleiner dan in maatschappijen met traditionele beleidsmodellen.

Deze bevindingen suggereren dat we niet a priori kunnen concluderen dat contextuele beleidseffecten gelijk zijn voor mannen en vrouwen. Wanneer we de houdingen van het grote publiek willen beïnvloeden, lijkt dit, enerzijds, te kunnen worden bereikt door beleid in te zetten op nationaal niveau dat stimuleert om vrouwen hun traditionele rollen te verlaten en dat alternatieve rollen voor vrouwen in de maatschappij mogelijk maakt. Anderzijds is weer gebleken dat individuele kenmerken als arbeidsdeelname en opleiding in sterke mate bepalen dat men minder steun uitspreekt voor traditionele rollen voor vrouwen in de maatschappij. Ook de beïnvloeding van deze individuele kenmerken is daarom een pad dat kan worden bewandeld om de steun voor traditionele vrouwenrollen te verminderen, en daarmee de emancipatie van vrouwen te bevorderen.

\section{Noten}

1. De eerste auteur kan bereikt worden op het volgende e-mailadres: stefanieandre@gmail.com. Stéfanie André is promovenda aan de afdeling methoden en technieken van onderzoek aan de Universiteit van Tilburg. Peer Scheepers is hoogleraar methodologie bij de leerstoelgroep Sociologie, Faculteit der Sociale Wetenschappen, Radboud Universiteit Nijmegen en Maurice Gesthuizen is universitair docent bij diezelfde leerstoelgroep. De auteurs danken de redactie van Mens \& Maatschappij voor hun waardevolle bijdragen aan dit artikel.

2. De resultaten van onze equivalentietesten zijn hier niet weergegeven, ze kunnen worden opgevraagd bij de eerste auteur. 


\section{Literatuur}

Amato, P.R. \& Booth, A. (1995). Changes in gender role attitudes and perceived marital quality. American Sociological Review, 60(1), 58-66.

Banaszak, L.A. \& Plutzer, E. (1993). Contextual determinants of feminist attitudes: national and subnational influences in Western Europe. American Political Science Review, 87(1), 147-157.

Berridge, D., Penn, R. \& Ganjali, M. (2009). Changing attitudes to gender roles: a longitudinal analysis of ordinal response data from the British Household Panel Study. International Sociology, 24(3), 346-367.

Bijbel, de. (2011). (www.bijbel-online.nl). Bezocht op: 20 januari 2011.

Bolzendahl, C.I. \& Myers, D.J. (2004). Feminist attitudes and support for gender equality: opinion change in women and men 1974-1998. Social Forces, 83(2), 769-790.

Bonoli, G. (1997). Classifying welfare-states: a two-dimension approach. Journal of Social Policy, 26(3), 351-372.

Boye, K. (forthcoming). Work and well-being in a comparative perspective - the role of family policy. European Sociological Review, 1-15.

Brewster, K.L. \& Padavic, I. (2000). Change in gender-ideology, 1977-1996: the contribution of intracohort change and population turnover. Journal of Marriage and the Family, 62(2), 477-487.

Brooks, C. \& Bolzendahl, C.I. (2004). The transformation of US gender role attitudes: cohort replacement, social structural change and ideological learning. Social Science Research, 33(1), 106-133.

Carter, J.S. Corra, M., \& Carter, S.K. (2009). The interaction of race and gender: changing gender role attitudes 1974-2006. Social Science Quarterly, 90(1), 196-211.

Cassidy, M.L. \& Warren, B.O. (1996). Family employment status and gender role attitude, a comparison of women and men college graduates. Gender \& Society, 10(3), 312-329.

Cherlin, A. \& Walters, P.B. (1981). Trend in United States men's and women's sex-role attitudes: 1972-1978. American Sociological Review, 46(4), 453-460.

Davis, N.J. \& Robinson, R.V. (1991). Men's and women's consciousness of gender inequality: Austria, West-Germany, Great-Brittain and the United States. American Sociological Review, 56(1), 72-84.

Downs, A. (1957). An economic theory of democracy. New York: Harper and Row.

Durkheim, E. (1922). Education et sociologie. Paris: Alcan/PUF.

Esping-Andersen, G. (1990). The three worlds of welfare capitalism. New Jersey: Princeton University Press.

Esping-Andersen, G. (1999). Social foundations of postindustrial economies. Oxford: Oxford University Press.

Europa.eu. (2010). Employment and social policy. Retrieved from http:// 
europa.eu/legislation_summaries/employment_and_social_policy/ equality_between_men_and_women/c10404_en.htm

Ferrarine, T. (2006). Familes, states and labour markets. Institutions, causes and consequences of family policy in post-war states. Cheltenham: Edward Elgar.

Ferrarini, T. (2006). Families, states and labour markets. Institutions, causes and consequences of family policy in post-war states. Cheltenham: Edward Elgar.

Ferrarini, T. \& Sjöberg, O. (forthcoming). Social policy and health: transition countries in a comparative perspective. International Journal of Social Welfare, 19(1), 60-88.

Ferrera, M. (1996). The "Southern" model of welfare in social Europe. Journal of European Social Policy, 6(1), 17-37.

Field, A. (2009). Discovering statistics. Understanding statistics using SPSS. Los Angelos: Sage.

Fridberg, T. \& Ploug, N. (2000). Public attitudes to unemployment in different European welfare regimes. In D. Gallie \& S. Paugam (eds.), Welfare regimes and the experience of unemployment in Europe (pp. 334-348). Oxford: Oxford University Press.

Gelissen, J. (2000). Popular support for institutionalised solidarity: a comparison among European welfare states. International Journal of Social Welfare, 9(4), 285-300.

Gesthuizen, M., Van der Meer, T. \& Scheepers, P. (2008). Education and dimensions of social capital: do educational effects differ due to educational expansion and social security expenditure? European Sociological Review, 24(5), 617-632.

Gibbons, B.L., Hamby, B.A. \& Dennis, W.D. (1997). Researching gender-role ideologies internationally and crossculturally. Psychology of Women Quarterly, 21(1), 151-170.

Gundelach, P. (1994). National value differences: modernization or institutionalization? International Journal of Comparative Sociology, 35(1/2), 37-58.

Guo, J. \& Gilbert, N. (2007). Welfare state regimes and family policy: a longitudinal analysis. International Journal of Social Welfare, 16(1), 1-7.

Harris, R.J. \& Firestone, J.M. (1998). Changes in predictors of gender role ideologies among women: a multivariate analysis. Sex Roles, 38(3/4), 239-252.

Hofstede, G. (1980). Culture's consequences: international differences in workrelated values. Beverly Hills (USA): Sage.

Hofstede, G. (2010). Masculinity Index, 2010, from http://www.geert-hofstede.com/hofstede_dimensions.php

ILO (2010a). Labour market participation Retrieved March 11th, 2010, from http://kilm.ilo.org/KILMnetBeta/default2.asp 
ILO (2010b). More women choosing to work, but gender equality remains a long way off Retrieved June 8th, 2010, from http://www.ilo.org/global/About_the_ILO/Media_and_public_information/Press_releases/ lang-en/WCMS_123827/index.htm'

ISSP (2010). International Social Survey Programme Retrieved December 9th 2009, from www.issp.org

Jansen, M. \& Kalmijn, M. (2000). Emancipatiewaarden en de levensloop van jong-volwassen vrouwen [emancipation values and the life course of young-adult women]. Sociologische Gids, 47(4), 293-314.

Kääriäinen, J. \& Lehtonen, H. (2006). The variety of social capital in welfare state regimes - a comparative study of 21 countries. European Societies, 9(1), 27-57.

Kane, E.W. (2000). Racial and ethnic variations in gender-related attitudes. Annual Review of Sociology, 26, 419-439.

Klein, E. (1984). Gender politics: from consciousness to mass politics. Cambridge: Harvard University Press.

Kohn, M.L. \& Schooler, C. (1982). Job conditions and personality: a longitudinal assessment of reciprocal effects. American Journal of Sociology, $87(6), 1257-1286$.

Koran, de. (2011). (http://www.koranonline.nl/koran/nl/index.php?subacti on $=$ showfull $\&$ id $=1099093589 \&$ archive $=\&$ start_from $=\& u c a t=2 \& g o=N L)$. Bezocht op: 20 januari 2011.

Korpi, W. (2000). Faces of inequality: gender, class, and patterns of inequalities in different types of welfare states. Social Politics, 7(2), 127-191.

Liebfried, S. (1992). Towards a European welfare-state? On integration poverty regimes in to the European community. In Z. Ferge \& J.E. Kolberg (eds.), Social policy in a changing Europe. Frankfurt am Main: Campus Verlag.

MacCullum, R.C., Browne, M.W. \& Sugawara, H.M. (1996). Power analysis and determination of sample size for covariance structure modelling. Psychological Methods 1(2), 130-149.

Mason, K.O. \& Lu, Y. (1988). Attitudes towards women's familial roles: changes in the United States 1977-1985. Gender \& Society, 2(1), 39-57.

Mernissi, F. (1985). Beyond the veil. Male-female dynamics in modern Muslim societies. London: AlSaqi Books.

Motiejunaite, A. \& Kravchenko, Z. (2008). Family policy, employment and gender-role attitudes: a comparative analysis of Russia and Sweden. Journal of European Social Policy, 18(1), 38-49.

Newman, D.M. (2000). Sociology. Exploring the architecture of everyday life. Third edition. Thousan Oaks: Pine Forge Press.

Panayatova, E. \& Brayfield, A. (1997). National context and gender ideology: attitudes toward women's employment in Hungary and the United States. Gender \& Society, 11(5), 627-655. 
Penn, R. \& Lambert, P. (2002). Attitudes to ideal family size. Population Trends, 108(1), 49-58.

Plutzer, E. (1988). Work life, family life and women's support of feminism. American Sociological Review, 53(4), 640-649.

Plutzer, E. (2002). Becoming a habitual voter. Political Science Review, 96(1), 41-56.

Saris, W.E., Satorra, A. \& Van der Veld, W.M. (2009). Testing structural equation models, or detection of misspecifications. Structural Equation Modelling, a multidisciplinary journal, 16(4), 453-465.

Scheepers, P. \& Te Grotenhuis, M. (2005). Who cares for the poor in Europe? Micro and macro determinants for alleviating poverty in 15 European countries. European Sociological Review, 21(5), 453-465.

Sjöberg, O. (2004). The role of family policy institutions in explaining gender-role attitudes: a comparative multilevel analysis of thirteen industrialized countries. Journal of European Social Policy, 14(2), 107-123.

Snijders, T.A.B. \& Bosker, R.J. (1999). Multilevel Analysis. An introduction to basic and advanced multilevel modelling. London: Sage Publications.

Stark, R. (2004). Sociology. Belmont: Thomson Wadsworth.

Svallfors, S. (1997). Worlds of welfare and attitudes to redistribution: a comparison of eight Western nations. European Sociological Review, 13(3), 283-304.

Vijver, F. van de \& Leung, K. (1997). Methods and data analysis for crosscultural research. Thousand Oaks: Sage Publications.

Veld, W.M. van der \& Saris, W.E. (eds.). (2010). Causes of generalized social trust: an innovative crossnational evaluation. New-York: Routledge.

Waite, L.J., Goldscheider, F.K. \& Witsberger, C. (1986). Nonfamily living and the erosion of traditional family orientations among young adults. American Sociological Review, 51(4), 541-554. 